УДК 37.032:378.147:62

DOI:

Ірина Пастирська, кандидат педагогічних наук, доцент кафедри іноземних мов

Ольга Якимович, кандидат педагогічних наук, провідний спеціаліст кафедри систем штучного інтелекту Наиіональний університет "Львівська політехніка"

\title{
ІНТЕГРАТИВНИЙ ПІДХІД ДО НАВЧАЛЬНОГО ПРОЦЕСУ В КОНТЕКСТІ СОЦАЛІЗАЦЇ̈ МАЙБУТНІХ ФАХІВЦІВ ТЕХНІЧНОГО ПРОФІЛЮ
}

У статті обтрунтувано доцільність інтегративного підходу як засобу соиіалізації студентів вищих технічних навчальних закладів. Запропоновано впровадження у навчальний прочес інтегративних курсів з метою вирішення проблеми співвідношення базових та гуманітарних предметів у вузах технічного профілю. У процесі соціалізації студентської молоді інтеграційні процеси спроможні забезпечити формування мотивачії до професійної діяльності, адаптації студентів і випускників в умовах реального сочіального середовища.

Ключові слова: сочіалізація; інтеграція; інтегративний підхід; навчальний процес; зміст освіти; професійна підготовка.

Jim. 6.

Iryna Pastyrska, Ph.D.(Pedagogy), Associate Professor of the Foreign Languages Department Olha Yakymovych, Ph.D.(Pedagogy), Leading Specialist of the Artificial Intelligence Systems Department Lviv Polytechnic National University

\section{INTEGRATIVE APPROACH TO THE EDUCATIONAL PROCESS IN THE CONTEXT OF SOCIALIZATION OF FUTURE TECHNICAL SPECIALISTS}

The article substantiates the expediency of the integrative approach as a means of socializing of students of higher technical education institutions.

The results of the theoretical and methodological analysis of the problem of socialization of the student youth and the leading role of professional environment in terms of its provision in modern conditions are presented. Turning to the discussion on the implementation of the continuity of technological and competence approaches in the field of education, the necessity of transition to interdisciplinary training based on the implementation of the subject-oriented approach is substantiated. It is revealed that the design of integral phenomena requires the integrated knowledge, interdisciplinary synthesis, construction of ideal images of socially oriented orientation. Correction of the procedure of early professionalization of the youth should be focused on the development of the individual, the formation of understanding of a new society, human capital, preservation and strengthening of human health.

Introduction of integration into the educational process is one of the possible ways of solving the problem of correlation of basic and humanitarian subjects in the technical institutes. Integration of education content, namely, presentation of relations and interrelations that exist between different educational courses, contributes to a holistic view of the world, nature, social phenomena and their dialectics. Integrative connections, from the position of specific training, do not break the structure and specificity of each training course, but harmoniously combine them into a common system of knowledge, abilities, skills and value orientations of the individual. The formation of a highly skilled specialist requires the provision of its multicomponent system of integrated multiobjective knowledge. The models of a modern specialist should ensure the formation of a comprehensive system of general and specialized knowledge through didactic means of all educational subjects, which is possible only with an integrative approach to learning.

In the process of socialization of the student youth, the integration processes are capable of ensuring the formation of motivation for professional activity, adaptation of students and graduates in conditions of real social environment. The main principles of the theory of pedagogical integration can be used to create the integrated courses of humanities at a technical university on a scientific basis.

Keywords: socialization; an integration; an integrative approach; an educational process; a content of education; the professional training.

П остановка проблеми. Тенденція до інтеграції знань випливає не лише 3 об'єктивного розвитку суспільства, науки та виробництва, але $\epsilon$ виявом природного потягу людського розуму і людської душі до єдності, цілісності та гармонії. Для сучасного суспільства необхідне формування спеціаліста, який здатний не лише творчо використовувати 


\section{ІНТЕГРАТИВНИЙ ПІДХІД ДО НАВЧАЛЬНОГО ПРОЦЕСУ В КОНТЕКСТІ СОЦІАЛІЗАЦІЇ МАЙБУТНІХ ФАХІВЦІВ ТЕХНІЧНОГО ПРОФІЛЮ}

інформацію, але й самостійно здобувати та застосовувати іiі на практиці у складних чи несподіваних ситуаціях, ставити завдання та знаходити шляхи їх вирішення. Творчий характер мислення виявляється у здатності переносу отриманих знань у нові ситуації, бачення аналогії у віддалених явищах, готовності видати необхідну інформацію в потрібний момент. Тому формування кваліфікованого фахівця вимагає забезпечити його багатокомпонентною системою інтегрованих різнопредметних знань.

Соціалізація студентської молоді розглядається як цілісний соціально-педагогічний феномен, що має специфічні педагогічні ознаки, а саме: мету, зміст, форми й технології реалізації, а також кінцевий результат - рівень соціалізованості особистості. Педагогічна підтримка соціалізанійного процесу у своїй змістовній основі містить перш за все систему позанавчальної діяльності. Філософське вчення про взаємозумовленість соціальних явищ і педагогічної дійсності та ідеї діалектичного розвитку особистості в результаті включення в різноманітні види діяльності передбачає включення інтеграційних механізмів у процес соціалізації.

Проблема інтеграції окремих явищ та процесів у педагогіці грунтовно досліджується, однак ряд iї аспектів залишаються малодослідженими. Серед них особливе місце займає інтеграція знань технічних та гуманітарних, наукових понять та художніх образів, елементів світогляду, цінностей вузькопрофесійних та духовних, загальнолюдських. Аналіз наукових праць, у яких розкрито особливості розвитку особистості під впливом соціального середовища й виховання (О. Асмолов, I. Бех, Л. Виготський, П. Гальперін, О. Леонтьєв, С. Рубінштейн Д. Фельдштейн, Г. Андрєєва, Н. Андрєєнкова, Ю. Істратов, І. Кон, О. Кущак, Н. Лавриченко, М. Лукашевич, В. Москаленко, А. Мудрик, В. Петрищев, О. Бєлінська, А. Волохов, Н. Голованова, Л. Єршова, О. Загородній, В. Схало, О. Кодатенко, Н. Срєбна) співзвучні з ідеями теорії соціалізації студентської молоді, які розкриті у законодавстві України про освіту й документах Міністерства освіти і науки (Закони України "Про освіту" та "Про вищу освіту", Національна доктрина розвитку освіти України в XXI столітті, інформаційні й нормативні матеріали Міністерства освіти і науки України).

Метою пропонованої статті є обгрунтування доцільності інтегративного підходу як засобу соціалізації студентів вищих технічних навчальних закладів.

В останні роки зростає актуальність загальнокультурної та гуманітарної підготовки фахівців у сфері технічних та природничих наук. 3 ускладненням інженерної діяльності різко розширилась сфера факторів, що визначають рівень професіоналізму. Наукова та технічна творчість, що характерна для інженерної діяльності, неможлива без високого рівня розвитку загального та професійного інтелекту, креативності особистості та розвиненої уяви. Вища школа повинна не лише давати вузькоспеціальну підготовку, але і формувати висококультурну, гуманну та моральну особистість, розвивати громадянські якості, вчити цивілізованим формам спілкування. У формуванні світоглядного, соціально-культурного аспекту професіоналізму у будь-якій сфері професійної діяльності значну роль відіграє соціально-гуманітарне знання.

Необхідність забезпечення високої фахової підготовки та духовного розвитку особистості вимагає вдумливого ставлення до побудови навчальних програм. Проблема співвідношення навчальних дисциплін, котрі забезпечують оволодіння професійними знаннями, та дисциплін, які формують духовний світ людини, пов'язана з рядом труднощів. При цьому виникає проблема перевантаження студентів навчальним матеріалом, якщо намагатися ізольовано включати у навчальний план як профілюючі, так і гуманітарні предмети. Разом з тим, відмова від вивчення гуманітарних предметів у технічному навчальному закладі теж не є виходом зі становища. Одним із можливих шляхів вирішення проблеми співвідношення базових та гуманітарних предметів у вузах технічного профілю є впровадження у навчальний процес інтеграції.

Як правило, говорячи про інтеграцію, перш за все розуміють їі використання для укладання навчальних планів основних предметів, наприклад, впровадження інтегративних курсів на основі комплексних чи гібридних наук (математичної фізики, будівельної фізики тощо). Проте в умовах вузу, де вся навчальна діяльність спрямована на оволодіння певною професією і весь навчальний процес підпорядкований формуванню фахівців певного профілю, особливе місце займають предмети, котрі не містять фактичного матеріалу, пов'язаного $з$ майбутньою професією студентів.

В сучасній освіті особливо важливу роль відіграє принцип інтеграції змісту освіти, тобто представлення взаємозв'язків й залежностей, які існують між різними навчальними курсами. Це сприяє цілісному баченню світу, природи, суспільних явищ та їх діалектики. Інтегративні 


\section{ІНТЕГРАТИВНИЙ ПІДХІД ДО НАВЧАЛЬНОГО ПРОЦЕСУ В КОНТЕКСТІ СОЦАЛІЗАЦІЇ МАЙБУТНІХ ФАХІВЦІВ ТЕХНІЧНОГО ПРОФІЛЮ}

зв’язки зв'язки з позиції конкретної професійної підготовки, не ламають структуру і специфіку кожного навчального курсу, а гармонійно поєднують їх в загальну систему знань, здібностей, навичок та ціннісних орієнтацій особистості. При цьому усуваються штучні демаркаційні рамки між традиційними, дуже вузько представленими навчальними предметами, а з'являються зв'язки і залежності між явищами, проблемами, процесами історичними і тематичнолітературними, філософськими, суспільними, політичними, мистецькими тощо.

Відомо, що існують два принципово відмінних підходи до освіти, кожний $з$ яких базується на певному розумінні людини: “людина-глина” - це образ формуючої педагогіки (людина в цьому випадку не має своєї “первинної” суті як “чистий листок” і є матеріалом для педагогічної роботи) та “людина-насінина”, яка має генетичну програму розвитку (освіта в цьому випадку спрямована на розвиток ії потенційних якостей, що реалізовуються в залежності від середовища, яке формується) $[5,27]$.

Проблеми міждисциплінарного характеру зумовлюють потребу інтеграції праці: вузька професія замінюються широкопрофільною. Наявність спільних рис у змісті, засобах, знаряддях та предметах праці привела до створення наскрізних професій, які є спільними для багатьох галузей. Об'єктивними передумовами інтеграції професій $є$ підвищення науково-технічного та технологічного рівня виробництва, зміна змісту праці, поява інваріанту у діяльності фахівців різних професій тощо. Інтеграція професій може здійснюватися на основі різних принципів. Моделі сучасного фахівця повинні забезпечувати формування цілісної системи загальноосвітніх та спеціальних знань дидактичними засобами всіх навчальних предметів, що можливе лише при інтегративному підході до навчання.

Нині сформувався особливий техногенний тип цивілізації, в якому під впливом інтенсивної інноваційної діяльності відбуваються активні соціальні зміни. Резерви росту черпаються вже не за рахунок розширення культурних зон, а за рахунок перебудови підвалин попередніх способів життєдіяльності та формування принципово нових можливостей. “Технократичне мислення, - зазначає С. У. Гончаренко, - це світогляд, істотними рисами якого є примат засобу над метою, часткової мети над смислом i загальнолюдськими інтересами і цінностями. Для технократичного мислення не існує категорій моральності, совісті, людських переживань і гідності” [1, 96]. Технократичне розуміння науково-технічного прогресу не сприяє нормальному розвитку психіки людини.

Гігантська техніка супроводжується технократичною ідеологією, а це шлях до морального регресу, оскільки технічний принцип "мета вимагає застосування всіх необхідних засобів” переноситься у сферу моралі, права, політики, що дає підстави людині із технократичним мисленням вважати, "що мета виправдовує засоби”, і діяти згідно 3 цим правилом: “істотно вплинути на цей феномен нашого буття має саме гуманістична переорієнтація вищої освіти і за структурою, і за змістом" $[2,41]$.

Об'єктивна єдність загальнокультурного, соціально-морального розвитку особистості спеціаліста, закладена в меті соціальнопедагогічної освіти, актуалізує формування у студентів професійно-педагогічної культури. Вона являє собою упорядковану сукупність загальнолюдських ідей, професійно-ціннісних орієнтацій та якостей особистості, універсальних способів пізнання і гуманістичної технології соціально-педагогічкої діяльності. Така культура дає змогу занурюватися у внутрішній світ людини, дитини, вивчати і діагностувати рівень їхнього розвитку, відкривати перед ними основи духовного життя людства. Отже, культурологічний підхід до формування змісту професійної підготовки створює умови для самовизначення студентів у культурі.

Напрями удосконалення педагогічної системи вищої школи відображують провідні об'єктивні тенденції розвитку, які чітко намітилися в передовому педагогічному досвіді та зумовили появу інноваційних технологій, форм і методів, засобів навчання, а водночас нових видів активності студентів, яким притаманні риси учіння і праці.

Л.І. Міщик зазначає, що педагогіка покликана сприяти подоланню відчуження кожної конкретної особистості від своєї справжньої соціальної природи. У цій ідеї найповніше втілюється гуманістична функція педагогіки. Тому підготовка майбутніх фахівців є практичного реалізацією цієї гуманістичної функції, особистісно орієнтованого підходу до їхнього навчання щодо змісту, так і форм та методів. Інший фактор зумовлюється сукупністю філософських, педагогічних, акмеологічних та інших позицій, які становлять зміст, продуктивні форми, стратегію та методи професійної підготовки студентів. Зміст професійної підготовки має відображати модель і технологію побудови навчального процесу на засадах 


\section{ІНТЕГРАТИВНИЙ ПІДХІД ДО НАВЧАЛЬНОГО ПРОЦЕСУ В КОНТЕКСТІ СОЦІАЛІЗАЦІЇ МАЙБУТНІХ ФАХІВЦІВ ТЕХНІЧНОГО ПРОФІЛЮ}

індивідуалізації та диференціації, особистісно орієнтованого підходу, результативності професійної діяльності майбутнього фахівця у рефлексивному середовищі [4].

Науково-технічне знання, яке раніше орієнтувалося переважно на використання досягнень природознавства, все частіше починає звертатися до проблем, вирішення яких має носити комплексний характер, вимагає використання специфіки методів гуманітарних наук.

Синтез соціального і природничо-наукового знання в більшій мірі буде здійснюватися опосередковано, через науки технічні, які в даний час крім природничо-наукового знання змушені все більше і глибше використовувати знання соціальних наук. Така тенденція сучасного технічного знання обумовлена не лише великим впливом техніки на соціальні процеси але і все більшим усвідомленням непереборності людини, суб'єктивного фактору, його соціальної обумовленості в світі техніки і технологій.

У процесі соціалізації студентської молоді загалом, інтеграційні процеси спроможні забезпечити ряд очікуваних педагогами вищої школи та суспільством результатів, зокрема формування мотивації, адаптації студентів і випускників в умовах реального соціального середовища тощо.

Соціокультурне середовище вищого навчального закладу розглядається як чинник, що забезпечує соціалізацію студентів як процес відтворювання та розвитку соціокультурної складової суспільства [6].

Як правило вважається, що формування образного, художнього мислення та розвиток художнього смаку це завдання виключно гуманітарних предметів. Однак значними резервами гуманітаризації навчання володіють i предмети природничо-математичного циклу. Це пов'язано $з$ тим, що практично протягом усього свого розвитку наукова думка опиралася на інтегральні критерії істини. Наука не просто копіювала дійсність, а висвітлювала творче ставлення до неї, створювала специфічні образи цієї дійсності засобами логічного мислення, звертаючись до свідомості людини. У той же час важко переоцінити роль уяви, фантазії, емоцій для відображення світу у художніх образах, які звертаються переважно до підсвідомості людини. Лише тісне поєднання свідомого і підсвідомого, логічного та інтуїтивно-емоційного мислення спроможне забезпечити цілісне та творче сприйняття навколишнього світу.

Інтегративний підхід до викладання навчальних предметів, на яке спрямовує сучасна дидактика, переростає від узгодження змісту освіти до глибокої взаємодії, обгрунтованої інтеграції знань, умінь та елементів мислення майбутнього фахівця. I для наукового, і для художнього мислення важливі такі його якості як оригінальність, гнучкість, глибина, цілеспрямованість, раціональність, широта, критичність, ясність тощо. Всі ці якості повноцінно формуються лише за інтегративного підходу до вивчення всіх навчальних предметів [3]. Разом 3 тим, у професійній школі існує ряд додаткових можливостей гуманітаризації курсів точних наук інтегративними засобами, пов'язаних 3 визначеністю характеру майбутньої професійної діяльності.

В умовах професійної освіти, де вся увага спрямована на оволодіння конкретною професією і весь навчальний процес підпорядкований формуванню фахівця, особливе місце займають предмети, які не містять фактичного навчального матеріалу, пов'язаного з професійними знаннями чи вміннями. Тому доцільною у ряді випадків $\epsilon$ інтеграція непрофільних предметів двома шляхами. По-перше, це включення певних відомостей з фундаментальних і прикладних наук у канву гуманітарних предметів 3 метою формування у майбутніх фахівців технічного профілю цілісного уявлення про природу, людину та суспільство. Наприклад, це ширші (ніж у загальноосвітній школі чи гуманітарних ліцеях) відомості про природодослідників та техніків, про історію техніки в контексті загальної історії людства та історії України. По-друге, це розробки інтегрованих курсів гуманітарних предметів, які б забезпечували формування повноцінної особистості випускника, і займали мінімум навчального часу.

Таким чином, теорія педагогічної інтеграції, яка зараз інтенсивно розвивається, її основні положення можуть бути використані для створення інтегрованих курсів гуманітарних предметів у технічному вузі на науковій основі. Адже точні технічні знання в поєднанні 3 гуманітарними сприятимуть вихованню не лише хороших фахівців, алей духовнобагатих особистостей. До подальших напрямів відносимо дослідження проблеми інтеграціїгуманітарних таприродничих наук для конкретних спеціальностей фахівців.

\section{ЛІТЕРАТУРА}

1. Гончаренко С. У. Зміст загальної освіти і її гуманітаризація / С. У. Гончаренко // Неперервна професійна освіта: проблеми, пошуки, перспективи. - К.: ВІПОЛ, 2000. - С. 81-107. 
2. Козаков В. А. Психолого-педагогічна підготовка в непедагогічних університетах / В. А. Козаков // Вища освіта України. - 2002. № 3. - С. 37-42.

3. Козловська I. М. Наука і мистецтво: інтеграційні аспекти / I. М. Козловська // Діалог культур. - 1998. - Вип.3. - С. 135-142.

4. Міщик Л. І. Теоретико-методологічні основи професійної підготовки соціального педагога у закладах вищої освіти: автореф. дис. на здобуття наук. ступеня докт. пед. наук: спец. 13.00.05 “Соціальна педагогіка" / Л. І. Міщик, - К., 1997. $-32 \mathrm{c}$.

5. Хуторской А. В. Современная дидактика / А. В. Хуторский. - СПб: Питер, 2001. - 544 с.

6. Якимович О.Н. Вплив середовища вищого навчального закладу на професійне виховання майбутніх фахівців / О.Н. Якимович, Я. В. Ільчишин // Сучасні інформаційні технології та інноваційні методики навчання в підготовці фахівців: методологія, теорія, досвід, проблеми // Зб. наук. пр. - Випуск 46 / редкол. - КиївВінниця: ФОП Тарнашинський О.В., 2016. C.350-354.

\section{REFERENCES}

1. Honcharenko, S. U. (2000). Zmist zahalnoi osvity i yii humanitaryzatsiia [Contents of general education and its humanization]. The continuous vocational education: the problems, searching, and perspectives. Kyiv: VIPOL, pp. 81-107. [in Ukrainian].

2. Kozakov, V. A. (2002). Psykholohopedahohichna pidhotovka $\mathrm{v}$ nepedahohichnykh universytetakh [Psychological-pedagogical training in non-pedagogical universities]. Higher education of Ukraine, no. 3, pp. 37-42. [in Ukrainian].

3. Kozlovska, I. M. (1998). Nauka i mystetstvo: intehratsiini aspekty [Contents of general education and its humanization]. The dialogue of culturec, vol.3, pp.135-142. [in Ukrainian].

4. Mishchyk, L. I. (1997). Teoretyko-metodolohichni osnovy profesiinoi pidhotovky sotsialnoho pedahoha u zakladakh vyshchoi osvity [The theoretical and methodological foundations of vocational training of social teacher in higher education institutions]. Extended abstract of Doctor's thesis. Kharkiv [in Ukrainian].

5. Khutorskoi, A. V. (2001). Sovremennaia dydaktyka [Modern Didactics]. Saint Petersburg: Pyter, 544 p. [in Russian].

6. Yakymovych, O. N. \& Ilchyshyn, Ya. V. (2016). Vplyv seredovyshcha vyshchoho navchalnoho zakladu na profesiine vykhovannia maibutnikh fakhivtsiv [Influence of the environment of a higher educational institution on professional education of future specialists]. The modern information technologies and innovative methods of training in the process of preparing the specialists: the methodology, theory, experience, and problems. No. 46, pp. 350-354. [in Ukrainian].

Стаття надійшла до редакції 12.03.2018

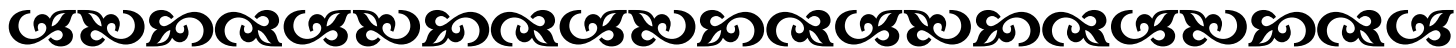

"Нам потрібні иінності не обов'язқово тақі, що суперечать одна одній, але $i$ не обов'язково такі, що узгоджуються".

$$
\begin{array}{r}
\text { Раймон Арон } \\
\text { браниузьжий соиіолог }
\end{array}
$$

"Dо вивчення наук веде подвійний шлях - авторитет та розум. У відношенні до часу (тобто в історичній традииії) панує авторитет, а у відношенні до суті справи розум. Авторитет буває частково божественний, частково людський, але істинний, міиний та найвищий авторитет є той, яқий зветься божественним".

Августин Аврелій

богослов раннвого християнства, церковний письменник,

"Розуміти, що справедливо, відчувати, що прекрасно, бажати добра, - ось мета інтелектуального життя".

Aрістокл Ллгатон давньогрецький бінособб

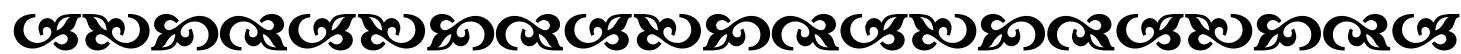

